\title{
Intracellular expression of purinoceptors
}

\author{
Geoffrey Burnstock ${ }^{1,2}$
}

Received: 12 May 2015 / Accepted: 15 May 2015 / Published online: 26 May 2015

(C) Springer Science+Business Media Dordrecht 2015

Purinoceptors, receptors for nucleosides and nucleotides, have been identified on the plasma membranes of many cell types [1]. The early hints and recent evidence for localization of purinoceptors on intracellular sites, including lysosomes [2-4], mitochondria [5, 6] and in nuclei where they open ion channels and appear to influence mRNA activity $[7,8]$, offers up a whole new aspect of purinergic signalling.

Purinergic signalling, ATP acting as an extracellular signalling molecule, was proposed in 1972 [9]. Separate families of purinergic receptors were recognised, named $\mathrm{P} 1$ receptors for adenosine and P2 receptors for ATP and ADP [10]. Two subtypes of $\mathrm{P} 2$ receptors were shown in 1985, based on pharmacology [11] and in the early 1990s P1, P2X and P2Y receptor subtypes were cloned and characterised: four subtypes of P1 receptors $\left(A_{1}, A_{2 A}, A_{2 B}\right.$ and $\left.A_{3}\right)$, seven subtypes of $P 2 X$ ion channel receptors $(\mathrm{P} 2 \mathrm{X} 1-7)$ and eight subtypes of $\mathrm{P} 2 \mathrm{Y} G$ protein-coupled receptors $\left(\mathrm{P} 2 \mathrm{Y}_{1}, \mathrm{P}_{2} \mathrm{Y}_{2}, \mathrm{P}_{2} \mathrm{Y}_{4}, \mathrm{P} 2 \mathrm{Y}_{6}, \mathrm{P} 2 \mathrm{Y}_{11}\right.$, $\mathrm{P}_{2} \mathrm{Y}_{12}, \mathrm{P}_{2} \mathrm{Y}_{13}$ and $\left.\mathrm{P} 2 \mathrm{Y}_{14}\right)[1,12]$.

Cloning of receptors made it possible to generate polyclonal antisera for immunohistochemical studies of their expression and distribution [13]. Many papers using this technique were published [14-17]. As expected, the receptors were located on the plasma membranes of cells, but sometimes there was also intracellular immunostaining. This was often dismissed by referees as artefacts. However, later studies have

Geoffrey Burnstock

g.burnstock@ucl.ac.uk

1 Autonomic Neuroscience Centre, University College Medical School, Rowland Hill Street, London NW3 2PF, UK

2 Department of Pharmacology and Therapeutics, The University of Melbourne, Melbourne, Australia revealed that intracellular localization of purinoceptors is genuine. For example, it was suggested that uptake of P2X1 receptors into smooth muscle cells of the rat vas deferens was responsible for desensitization ([18] and see [19]). $\mathrm{P} 2 \mathrm{Y}_{2}$ receptor internalization via the clathrin-mediated pathway was observed in HEK293 cells using receptors tagged with green fluorescent protein (GFP), to be colocalized with endosomes and lysosomes [2]. GFP was also used to show internalization of $\mathrm{P} 2 \mathrm{Y}_{1}$ receptors in HEK-293 cells [20, 21]. Ser352 and Ser354 in the carboxyl terminus of human $\mathrm{P}_{2} \mathrm{Y}_{1}$ receptors were shown to be needed for internalization in MDCK cells [22]. P2X3 receptors transfected into HEK-293 cells and expressed endogenously in dorsal root ganglion sensory neurons undergo rapid constitutive endocytosis, targeting the late endosomal/lysosomal system [23]. The role of internalised P2X7 receptors on lysosomes in macrophages in the killing of mycobacteria is discussed in a review [24]. A Rab5dependent pathway was described for internalisation of P2X4 receptors in HEK-293 cells [25]. The internalised P2X4 receptors are located on lamellar bodies, lysosomes, vesicles and vacuoles in HEK-293 cells, hippocampal neurons and alveolar type II cells [3, 4]. P2X4 receptor channel activity was directly measured in intact lysosomes in HEK-239 cells [26]. Both ATP and P2X4 receptors were present in lysosomes and the lysosomal P2X4 receptors were activated by ATP at the luminal side in a $\mathrm{pH}$-dependent manner. The lysosomal P2X4-mediated responses were potentiated by ivermectin, but were insensitive to suramin and PPADS, as for the plasma membrane $\mathrm{P} 2 \mathrm{X} 4$ receptors. Mitochondrial calcium transport was shown to be regulated by $\mathrm{P}_{2} \mathrm{Y}_{1}$ - and $\mathrm{P} 2 \mathrm{Y}_{2}$-like mitochondrial receptors from rat liver cells [5]. ATP, acting on the nuclear envelope, was reported to open ion channels in both Xenopus oocytes [27, 28] and patch-clamped isolated mouse liver nuclei [29]. It was later reported that $\mathrm{P} 2 \mathrm{X} 7$ receptors were expressed in the outer nuclear membranes of rat 
hippocampal inhibitory neurons [7]. P2X7 receptor immunoreactivity was also shown on the nuclear membrane of guinea pig visceral smooth muscle cells [30]. Studies of the expression of P2X-like receptors in amoeba showed that most of the immunostaining was on the membranes of intracellular vacuoles, required for osmoregulation, rather than on the plasma membrane [31-33], encouraging further investigations of intracellular localization of $\mathrm{P} 2$ receptors in mammals.

A recent paper showed immunostaining of $\mathrm{P} 2 \mathrm{X} 6$ receptors within the nucleus of cultured hippocampal neurons [8]. It was shown that once inside the nucleus, the P2X6 receptor interacts with the splicing factor $3 \mathrm{~A} 1$, which results in a reduction of the mRNA splicing activity, which is relevant in the ageing process.

These findings open up a whole new aspect of purinergic signalling and new studies will be of much interest.

\section{References}

1. Ralevic V, Burnstock G (1998) Receptors for purines and pyrimidines. Pharmacol Rev 50:413-492

2. Tulapurkar ME, Schäfer R, Hanck T, Flores RV, Weisman GA, González FA, Reiser G (2005) Endocytosis mechanism of P2Y nucleotide receptor tagged with green fluorescent protein: clathrin and actin cytoskeleton dependence. Cell Mol Life Sci 62:13881399

3. Qureshi OS, Paramasivam A, Yu JC, Murrell-Lagnado RD (2007) Regulation of $\mathrm{P} 2 \mathrm{X}_{4}$ receptors by lysosomal targeting, glycan protection and exocytosis. J Cell Sci 120:3838-3849

4. Xu J, Chai H, Ehinger K, Egan TM, Srinivasan R, Frick M, Khakh BS (2014) Imaging P2X4 receptor subcellular distribution, trafficking, and regulation using P2X4-pHluorin. J Gen Physiol 144:81104

5. Belous A, Wakata A, Knox CD, Nicoud IB, Pierce J, Anderson CD, Pinson CW, Chari RS (2004) Mitochondrial P2Y-Like receptors link cytosolic adenosine nucleotides to mitochondrial calcium uptake. J Cell Biochem 92:1062-1073

6. Belous AE, Jones CM, Wakata A, Knox CD, Nicoud IB, Pierce J, Chari RS (2006) Mitochondrial calcium transport is regulated by $\mathrm{P}_{2} \mathrm{Y}_{1}$ - and $\mathrm{P}_{2} \mathrm{Y}_{2}$-like mitochondrial receptors. J Cell Biochem 99: $1165-1174$

7. Atkinson L, Milligan CJ, Buckley NJ, Deuchars J (2002) An ATPgated ion channel at the cell nucleus. Nature 420:42

8. Díaz-Hernández JI, Sebastián-Serrano A, Gómez-Villafuertes R, Díaz-Hernández M, Miras-Portugal MT (2015) Age-related nuclear translocation of $\mathrm{P} 2 \mathrm{X} 6$ subunit modifies splicing activity interacting with splicing factor 3A1. PLoS One 10:e123121

9. Burnstock G (1972) Purinergic nerves. Pharmacol Rev 24:509-581

10. Burnstock G (1978) A basis for distinguishing two types of purinergic receptor. In: Straub RW, Bolis L (eds) Cell membrane receptors for drugs and hormones: a multidisciplinary approach. Raven, New York, pp 107-118

11. Burnstock G, Kennedy C (1985) Is there a basis for distinguishing two types of $\mathrm{P}_{2}$-purinoceptor? Gen Pharmacol 16:433-440

12. Burnstock G (2007) Purine and pyrimidine receptors. Cell Mol Life Sci 64:1471-1483

13. Oglesby IB, Lachnit WG, Burnstock G, Ford APDW (1999) Subunit specificity of polyclonal antisera to the carboxy terminal regions of P2X receptors, $\mathrm{P}_{2} \mathrm{X}_{1}$ through $\mathrm{P}_{2} \mathrm{X}_{7}$. Drug Dev Res 47:189-195

14. Chan CM, Unwin RJ, Bardini M, Oglesby IB, Ford APDW, Townsend-Nicholson A, Burnstock G (1998) Localization of
$\mathrm{P} \mathrm{X}_{1}$ purinoceptors by autoradiography and immunohistochemistry in rat kidneys. Am J Physiol 274:F799-F804

15. Llewellyn-Smith IJ, Burnstock G (1998) Ultrastructural localization of $\mathrm{P} 2 \mathrm{X}_{3}$ receptors in rat sensory neurons. Neuroreport 9: 2545-2550

16. Gröschel-Stewart U, Bardini M, Robson T, Burnstock G (1999) Localisation of $\mathrm{P} 2 \mathrm{X}_{5}$ and $\mathrm{P} 2 \mathrm{X}_{7}$ receptors by immunohistochemistry in rat stratified squamous epithelia. Cell Tissue Res 296:599605

17. Gröschel-Stewart U, Bardini M, Robson T, Burnstock G (1999) $\mathrm{P} 2 \mathrm{X}$ receptors in the rat duodenal villus. Cell Tissue Res 297: $111-117$

18. Ennion SJ, Evans RJ (2001) Agonist-stimulated internalisation of the ligand-gated ion channel $\mathrm{P}_{2} \mathrm{X}_{1}$ in rat vas deferens. FEBS Lett 489:154-158

19. Mueller A (2007) Internalization: what does it tell us about pharmacokinetic and pharmacodynamic properties of an antagonist? $\mathrm{Br}$ J Pharmacol 152:1145-1146

20. Tulapurkar ME, Zündorf G, Reiser G (2006) Internalization and desensitization of a green fluorescent protein-tagged $\mathrm{P}_{2} \mathrm{Y}_{1}$ nucleotide receptor are differently controlled by inhibition of calmodulindependent protein kinase II. J Neurochem 96:624-634

21. Reiner S, Ziegler N, Leon C, Lorenz K, von Hayn K, Gachet C, Lohse MJ, Hoffmann C (2009) $\beta$-Arrestin-2 interaction and internalization of the human $\mathrm{P} 2 \mathrm{Y}_{1}$ receptor are dependent on $\mathrm{C}$-terminal phosphorylation sites. Mol Pharmacol 76:1162-1171

22. Qi AD, Houston-Cohen D, Naruszewicz I, Harden TK, Nicholas RA (2011) Ser352 and Ser354 in the carboxyl terminus of the human $\mathrm{P}_{2} \mathrm{Y}_{1}$ receptor are required for agonist-promoted phosphorylation and internalization in MDCK cells. Br J Pharmacol 162: 1304-1313

23. Vacca F, Giustizieri M, Ciotti MT, Mercuri NB, Volonté C (2009) Rapid constitutive and ligand-activated endocytic trafficking of $\mathrm{P} 2 \mathrm{X}_{3}$ receptor. J Neurochem 109:1031-1041

24. Qu Y, Dubyak GR (2009) P2X7 receptors regulate multiple types of membrane trafficking responses and non-classical secretion pathways. Purinergic Signal 5:163-173

25. Stokes L (2013) Rab5 regulates internalisation of P2X4 receptors and potentiation by ivermectin. Purinergic Signal 9:113-121

26. Huang P, Zou Y, Zhong XZ, Cao Q, Zhao K, Zhu MX, MurrellLagnado R, Dong XP (2014) P2X4 forms functional ATP-activated cation channels on lysosomal membranes regulated by luminal $\mathrm{pH}$. J Biol Chem 289:17658-17667

27. Mazzanti M, Innocenti B, Rigatelli M (1994) ATP-dependent ionic permeability on nuclear envelope in in situ nuclei of Xenopus oocytes. FASEB J 8:231-236

28. Shahin V, Danker T, Enss K, Ossig R, Oberleithner H (2001) Evidence for $\mathrm{Ca}^{2+}$ - and ATP-sensitive peripheral channels in nuclear pore complexes. FASEB J 15:1895-1901

29. Assandri R, Mazzanti M (1997) Ionic permeability on isolated mouse liver nuclei: influence of ATP and Ca2+. J Membr Biol 157:301-309

30. Menzies J, Paul A, Kennedy C (2003) P2X7 subunit-like immunoreactivity in the nucleus of visceral smooth muscle cells of the guinea pig. Auton Neurosci 106:103-109

31. Fountain SJ, Parkinson K, Young MT, Cao L, Thompson CR, North RA (2007) An intracellular P2X receptor required for osmoregulation in Dictyostelium discoideum. Nature 448:200-203

32. Ludlow MJ, Durai L, Ennion SJ (2009) Functional characterization of intracellular Dictyostelium discoideum P2X receptors. J Biol Chem 284:35227-35239

33. Parkinson K, Baines AE, Keller T, Gruenheit N, Bragg L, North RA, Thompson CR (2014) Calcium-dependent regulation of Rab activation and vesicle fusion by an intracellular P2X ion channel. Nat Cell Biol 16:87-98 